\title{
Roost use by bats in Espírito Santo, Brazil: comparison of a protected area, a rural landscape, and an urban landscape
}

\author{
Poliana Mendes ${ }^{1}$, Thiago Bernardi Vieira' ${ }^{1}$, Monik Oprea ${ }^{1}$, Daniel Brito ${ }^{2}$ and Albert David Ditchfield ${ }^{3}$ \\ 'Programa de Pós-Graduação em Ecologia e Evolução - Instituto de Ciências Biológicas (Bloco ICB IV) da Universidade Federal de Goiás, Campus II/ \\ UFG, Goiânia, Goiás, 74001-970; polimendes@gmail.com \\ ${ }^{2}$ Laboratório de Ecologia Aplicada e Conservação, Departamento de Biologia Geral, Instituto de Ciências Biológicas (Bloco ICB IV) da Universidade \\ Federal de Goiás, Campus II/UFG, Goiânia, Goiás, 74001-970. \\ ${ }^{3}$ Laboratório de Estudos de Quirópteros, Departamento de Ciências Biológicas, Universidade Federal do Espírito Santo, Avenida Marechal Campos \\ 1468, Maruípe, Vitória, Espírito Santo, ES 29040-090, Brasil.
}

Received 29-IV-2011 Corrected 21-VII-2011 Accepted 5-VIII-2011

\begin{abstract}
Bats use a wide array of roosts that have several important roles for bats. The present study was conducted in three areas in the state of Espírito Santo, southeastern Brazil: a protected area, a rural landscape, and an urban landscape. In each area we actively searched for roosts, and when one was found we set mist-nets (from one to four, depending on roost size) close to the roost entrance. These mist-nets stayed open from three to six hours after sunset. We observed bats using several types of roosts: hollow trees, foliage, caves, rock crevices, buildings, abandoned houses, bridges, and rain pipes. We found a total of 12 roosts, four in each sampled area. To our knowledge we present the first record of Lonchorhina aurita using man-made roosts. Roosts are of paramount importance to the persistence of bat populations. Therefore, bat roost ecology will play a vital role in managing and conserving bat species.
\end{abstract}

\section{KEY WORDS}

Roost ecology, urban landscape, rural landscape, Atlantic Forest, Chiroptera.

\section{RESUMEN}

Los murciélagos utilizan una variedad de refugios, con funciones diferentes e importantes en la ecología del grupo. El conocimiento de estos refugios es importante en su gestión y conservación. Este estudio se realizó en tres localidades de Espíritu Santo, sudeste de Brasil: (1) Colina de Vargas (una zona protegida), (2) un paisaje rural, y (3) un paisaje urbano. En estas tres áreas se llevó a cabo la búsqueda activa de refugiospara instalar entre una y cuatro redes de niebla (dependiendo del tamaño del refugio) cerca de la entrada principal del refugio. Las redes se mantuvieron activas 3-6 horas después del atardecer. Se encontró un total de 12 refugios, cuatro en cada área, incluyendo: huecos de árboles, follaje, cuevas, grietas de las rocas, edificios, casas abandonadas, puentes y tuberías de aguas pluviales. Este es el primer registro de refugio natural de Lonchorhina aurita.

\section{PALABRAS CLAVE}

Ecología de refugios, paisaje urbano, paisaje rural, Atlántico, Chiroptera.
Bats use a wide array of roosts, of both natural and human origin (Kunz \& Lumsden 2003). Day roosts are generally used for protection against predators and weather, for resting, and for social interactions (Keeley \& Tuttle 1999, Kunz 1982). Night roosts are generally used for feeding, between foraging periods (Keeley \& Tuttle 1999). Roost ecology entails complex interactions among physiological, demographic, and behavioral responses and morphological adaptations (Kunz 1982, Kerth et al. 2001). Roost selection may be influenced by roost abundance and availability, predation risk, abundance and distribution of food resources, abiotic factors and social structure (Kunz 1982, Menzel et al. 2002, Moussy 2011).

Approximately half of the bat species use plants as roosts (e.g. trunk hollows, foliage, etc.). Other species roost in caves, rock crevices, and human structures like tombs, mines, bridges and buildings. Some species also use cavities built by other animals (e.g. termite nests, ant mounds, old bird nests, etc.) (Kunz \& Lumsden 2003). Bat-roost association may vary from opportunistic to obligatory. It is 
difficult to formulate generalizations regarding roost selection because environmental and evolutionary selective pressures are different for each species (Kunz 1982). For example, factors affecting bats that roost in caves may be rather distinct from those affecting bats roosting in foliage. More protected roosts, like caves, have the advantages of a longer temporal existence, higher microclimatic stability, lower risk of predation, and protection against the weather (Kunz 1982). These characteristics maintain bats closest to their thermoneutral zone, the temperature in which bats spend minimum energy on thermoregulation (Neuweiler 2000). External roosts (e.g. foliage) are more abundant and more easily found, but have shorter temporal existence and are more susceptible to weather conditions (Kunz 1982, Rodriguez-Herrera et al. 2008).

Bats that differ in physiology and ecology use roosts in different ways (Silva 1979). For example, in Mexican caves, bats of the family Vespertilionidae use colder caves $(1,6$ to $29,8^{\circ} \mathrm{C}$ ), while Emballonuridae, Mormoopidae, Phyllostomidae, and Natalidae use warmer caves $\left(14,5\right.$ to $\left.37,5^{\circ} \mathrm{C}\right)$ (Ávila-Flores \& Mendellín 2004). There still is an astounding lack of knowledge on roost ecology for a large number of bat species (Fenton et al. 2000). The goal of this study was to report data on roost use by bats, in three localities of state of Espírito Santo, southeastern Brazil. A total of 63 species of bats are recorded in the state of Espírito Santo (Mendes et al. 2010). However, the state's bat fauna is far from being well-known, because Espírito Santo is the least sampled state in southeastern Brazil (Bergallo et al. 2003). Until now, there are only two studies on bat roost ecology in the state, focusing on Vampyressa pusilla and Rhinophylla pumilio (Zortéa 1995, Zortéa \& Brito 2000).

\section{METHODOLOGY}

The study was conduted in the state of Espírito Santo, southeastern Brazil. Three areas with different landscapes were sampled: (1) "Área de Relevante Interesse Ecológico Morro da Vargem" (ARIE Morro da Vargem), a private protected area ( $19^{\circ} 53^{\prime} 28^{\prime \prime} \mathrm{S}$ and $\left.40^{\circ} 22^{\prime} 43^{\prime \prime} \mathrm{W}\right)$; (2) a rural area in the municipality of Alfredo Chaves $\left(20^{\circ} 38^{\prime} 09^{\prime \prime} S\right.$ and $40^{\circ} 44^{\prime} 57^{\prime \prime} \mathrm{W}$ ); and (3) a urban area in the city of Vitória $\left(20^{\circ} 19^{\prime} 19^{\prime \prime} \mathrm{S}\right.$ and $\left.40^{\circ} 20^{\prime} 17^{\prime \prime} \mathrm{W}\right)$ (Fig. 1).

The "Área de Relevante Interesse Ecológico Morro da Vargem" is a 120ha private protected area, comprising Atlantic Forest remnants in different successional seres. In the municipality of Alfredo Chaves, we sampled a rural landscape characterized by Atlantic Forest fragments embedded into an agricultural matrix, mainly plantations of coffee (Coffea arabica Linnaeu) and banana (Musa paradisiaca Linnaeus). We also conducted samplings, in the

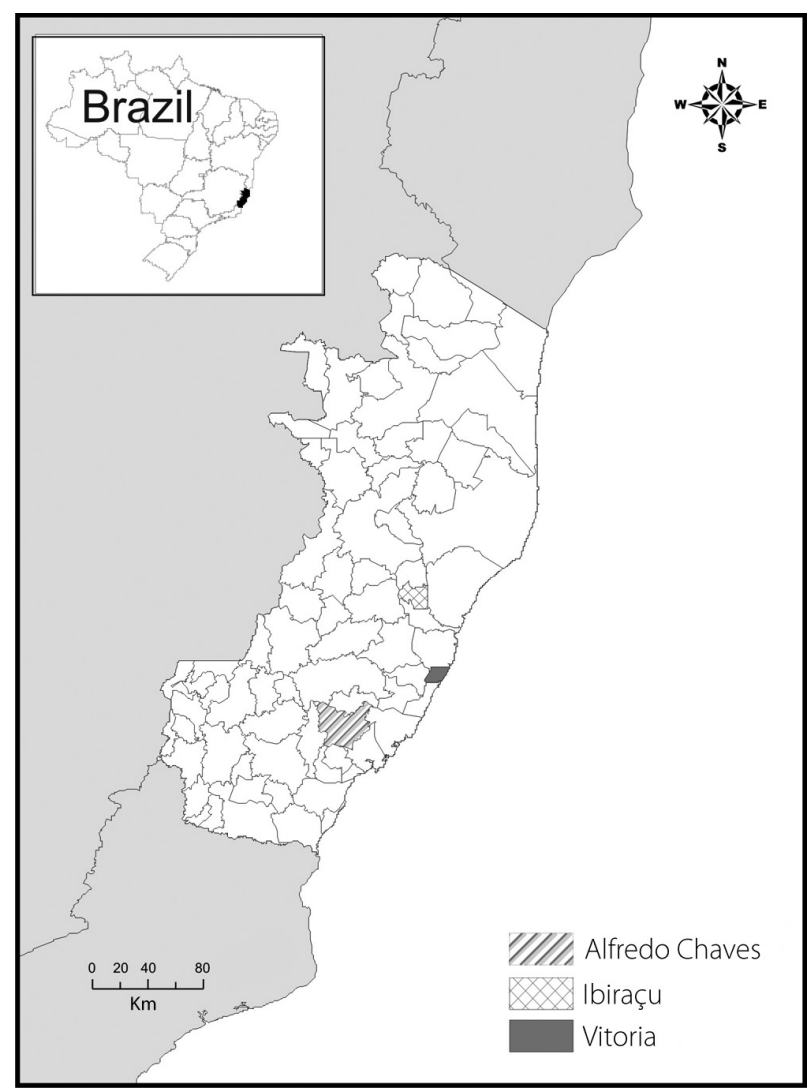

FIG. 1. Location of areas surveyed for bat roosts observed in the state of Espírito Santo, Brazil, August 2006 to July 2007.

urban landscape of Vitoria, composed by urban parks embedded in an urban matrix.

We searched for natural (e.g. caves, trees) and manmade (e.g. buildings) bat roosts in each of these areas. Whenever a roost was found, we tried to capture bats using mist-nets positioned in, or close to, the entrance of the roost. We used between one and four mist-nets $(9 \times 2,5 \mathrm{~m})$, depending on roost size and number of entrances. Mistnets were opened at sunset and stayed open for six hours.

Roosts searches were conducted in the same dates as mistnetting. In the Área de Relevante Interesse Ecológico Morro da Vargem, we conducted a total of two nights of capture per month, between August 2006 and July 2007, totaling 24 nights of sampling effort. In the municipality of Alfredo Chaves, we also conducted a total of two nights of capture per month, between September 2006 and July 2007, totaling 24 nights of sampling effort. In the urban landscape of Vitória, we conducted we conducted monthly samplings, comprising three days each, from September 2006 to July 2007, for a total of 30 nights 
We identified all captured bats using several available identification keys (e. g. Vizotto \& Taddei 1973, Gregorin \& Taddei 2002, Gardner 2007). Each captured individual was marked, using a coded collar, adapted from the technique proposed by Esbérard \& Daemon (1999). Voucher specimens were temporarily deposited at the Laboratory of Chiroptera Studies at the Federal University of Espírito Santo (Laboratório de Estudos de Quirópteros da Universidade Federal do Espírito Santo; LABEQ-UFES), and will later be sent to the Museu de Biologia Professor Mello Leitão, in Santa Teresa, Espírito Santo.

\section{RESULTS}

We found a total of twelve roosts, seven natural (e.g. trees, caves, rock crevices) and five manmade (bridges, buildings, rain pipes) (Table 1). At the Área de Relevante Interesse Ecológico Morro da Vargem we found three types of roosts: (1) a cave where we captured 25 individuals of Carollia perspicillata (Fig. 2), eight individuals of Anoura caudifer, two individuals of Lonchorhina aurita and one individual each of Diphylla ecaudata, Tonatia bidens and Trachops cirrhosus; (2) two rain pipes (1,5m diameter), in one we captured L. aurita (27 individuals), T. cirrhosus (7 individuals) and Desmodus rotundus ( 2 individuals) and in the other we observed 20 individuals of $D$. rotundus; and
(3) a building, where bats were observed roosting under a wooden roof, and we captured 65 Molossus molossus.

In the rural landscape in the municipality of Alfredo Chaves we found four kinds of roosts: (1) a cave $\left(20^{\circ} 39^{\prime} 49.00^{\prime \prime} \mathrm{S}\right.$ and $\left.40^{\circ} 46^{\prime} 31.00^{\prime \prime} \mathrm{W}\right)$ located in an area of pasturelands and banana plantations, and where we observed 20 individuals of C. perspicillata; (2) a bridge over the Joeba river in the road ES $146\left(20^{\circ} 39^{\prime} 28,00^{\prime \prime} S\right.$ and $\left.40^{\circ} 44^{\prime} 49,00^{\prime \prime} \mathrm{W}\right)$, where we observed separate colonies of C. perspicillata and Rhynchonycteris naso and we captured one individual of each species (Fig. 2); (3) a hollow in a Ficus sp. tree located in a pastureland $\left(20^{\circ} 39^{\prime} 26.00^{\prime \prime} \mathrm{S}\right.$ and $40^{\circ} 45^{\prime} 39,00^{\prime \prime} \mathrm{W}$ ), where we observed at least eight individuals (and captured four) Phyllostomus hastatus roosting in the upper portion of the cavity and some Molossus rufus, roosting below (31 individuals were captured). All captured individuals (both $P$. hastatus and M. rufus) presented a reddish tone in their fur, similar to the wood coloration in the interior of the hollow; and (4) an abandoned house $\left(20^{\circ} 40^{\prime} 12,00^{\prime \prime} \mathrm{S}\right.$ and $\left.40^{\circ} 45^{\prime} 43,00^{\prime \prime} \mathrm{W}\right)$ where we observed a colony of C. perspicillata (and captured four individuals).

In the urban landscape of Vitória we found two types of roosts: (1) palm tree leaves and (2) rock crevices. We found two roosts in palm tree leaves within the Federal University

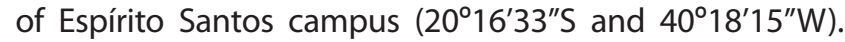
We observed nine individuals of Artibeus lituratus roosting

TABLE 1

List of bat species found in each roost in all three areas.

\begin{tabular}{|c|c|c|}
\hline Area & Roost & Species \\
\hline \multirow{4}{*}{ Protected Area } & Cave (4 mist nets/ two nights) & $\begin{array}{l}\text { Carollia perspicillata (25), Anoura caudifer (8), } \\
\text { Diphylla ecaudata (1), Lonchorhina aurita (2), } \\
\text { Trachops cirrhosus (1) and Tonatia bidens (1) }\end{array}$ \\
\hline & Rain pipe 1 (2 mist nets/ 2 nights) & $\begin{array}{l}\text { Lonchorhina aurita (27), Trachops cirrhosus(7) } \\
\text { and Desmodus rotundus ( } 2 \text { ) }\end{array}$ \\
\hline & Rain pipe 2 (visualization) & Desmodus rotundus (20) \\
\hline & Building (1 mist net/ 1 night) & Molossus molossus (65) \\
\hline \multirow{4}{*}{ Rural Landscape } & Cave (visualization) & Carollia perspicillata (20) \\
\hline & Hollow tree (4 mist nets/ 1 night) & Molossus rufus (31) and Phyllostomus hastatus (8) \\
\hline & Bridge (4 mist nets/ 1 night) & Rhynchonycteris naso (1) and Carollia perspicillata (1) \\
\hline & Abandoned house (4 mist nets/ 1 night) & Carollia perspicillata (4) \\
\hline \multirow{4}{*}{ Urban Landscape } & Palm foliage 1 (visualization) & Artibeus lituratus (9) \\
\hline & Palm foliage 2 (visualization) & Platyrrhinus lineatus (5) \\
\hline & Rock crevice 1 (1 mist net/ 1 night) & Peropteryx macrotis (1) \\
\hline & Rock crevice 2 ( 1 mist net/ 1 night) & Nyctinomops laticaudatus (5) \\
\hline
\end{tabular}



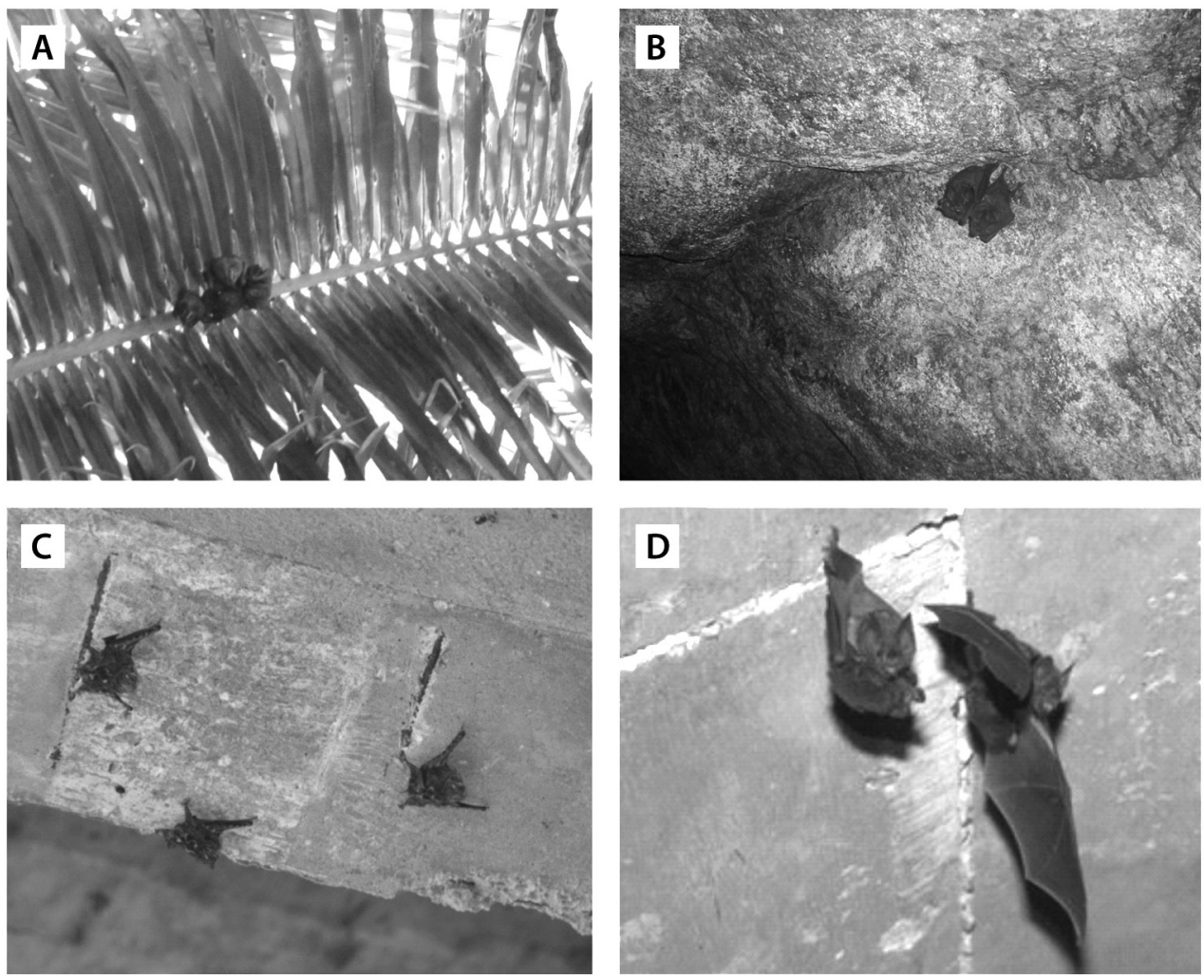

FIG. 2. Examples roosts of (A) Artibeus lituratus roosting in coconut palm leaves, within an urban area, Vitória (Photo: Monik Oprea); (B) Carollia perspicillata in a small cave in the Área de Relevante Interesse Ecológico Morro da Vargem, Ibiraçu (Photo: Poliana Mendes); (C) Rhynchonycteris naso (Photo: Cristiano Pordeus Garrido) and (D) Carollia perspicillata roosting under a bridge over the Joeba river on road ES 146, Alfredo Chave (Photo: Thiago Bernardi Vieira).

See this photograph in full color in the digital version (www.uned.ac.cr/investigacio/publicaciones/cuaderno1/).

in the leaves of a coconut palm tree (Cocos nucifera) (Fig. 2) and five individuals of Platyrrhinus lineatus roosting in the leaves of a Chinese fan palm (Livistona chinensis). We also found two roosts in rock crevices within Pedra da Cebola Municipal Park $\left(20^{\circ} 16^{\prime} 39^{\prime \prime}\right.$ S and $\left.40^{\circ} 17^{\prime} 45^{\prime \prime} \mathrm{W}\right)$, a small urban park in Vitória $\left(100000 \mathrm{~m}^{2}\right)$. In the first rock crevice we captured one individual of Peropteryx macrotis and in the other we captured five individuals of Nyctinomops laticaudatus.

\section{DISCUSSION}

\section{Natural internal roosts}

C. perspicillata is cited to be among the most abundant bat species to roost in caves in Brazil (Trajano 1995), and our results seem to corroborate this because we observed C. perspicillata roosting in caves both in the protected area and in the rural landscape. All of the species captured or observed roosting in caves in this study had already been reported to use this kind of roost: $A$. caudifer (Esbérard et al. 2005), C. perspicillata (Cloutier \& Tomas 1992, Esbérard et al. 2005), D. ecaudata (Greenhall et al. 1984, Esbérard et al. 2005), L. aurita (Lassieur \& Wilson 1989, Esbérard et al. 2005), T. bidens (Esbérard \& Bergallo 2004, Esbérard et al. 2005), T. cirrhosus (Cramer et al. 2001, Esbérard et al. 2005). C. perspicillata and A. caudifer have already been recorded to share the same roost (Esbérard et al. 2005). In the cave located in the protected area we observed only C. perspicillata and A. caudifer sharing the roost during the day, whereas other species also roosted in the cave during the night.

$N$. laticaudatus and $P$. macrotis are known to roost in rock crevices (Yee 2000, Ávila-Flores et al. 2002, Fabian 
\& Gregorin 2007, Peracchi \& Nogueira 2007), as we observed in the Pedra da Cebola Municipal Park in the urban landscape of Vitória. Bats of the family Molossidae are known to roost in tree hollows (Taddei et al. 1976), and we found $M$. rufus sharing a tree hollow roost with $P$. hastatus. We observed that $M$. rufus individuals stayed hidden in wooden crevasses within the hollow, maybe as a protection against opportunistic predation by $P$. hastatus from the colony above, because $P$. hastatus is known to predate other bats (Santos et al. 2003, Oprea et al. 2006).

\section{Natural external roosts}

A. lituratus and $P$. lineatus seem quite tolerant of habitat fragmentation and urbanization (Barros et al. 2006), and are commonly found in urban zones in Brazil (Oprea 2007, Zortéa 2007). They usually roost in the canopy of palm trees, under the leaves (Zortéa 2007), as we observed.

\section{Manmade roosts}

C. perspicillata is known to roost in a wide variety of manmade structures, including rain pipes, sewer systems and buildings (Ortêncio-Filho et al. 2007). We observed it roosting in a dark corner of a bridge in a rural area (Fig. 2). R. naso is usually found in well-illuminated roosts over water, on bridges, cave entrances, tree trunks, and rocks (Plumpton \& Jones 1992, Nogueira \& Pol 1998, Peracchi \& Nogueira 2007) (Fig. 2). Our results are similar. M. molossus is commonly found inhabiting buildings and beneath the roofs of houses (Fabian \& Gregorin 2007), as per our observations.

$T$. cirrhosus and $D$. rotundus are already well known to roost in rain pipes (Cramer et al. 2001, Aguiar 2007). Though L. aurita is usually found in forests (Handley Jr. 1976, Portfors et al. 2000), it has already been observed in agricultural landscapes (Handley Jr. 1976). L. aurita is not frequently recorded in surveys and higher capture rates are generally associated with sampling in caves (Lasseiur \& Wilson 1989, Esbérard et al. 2005, Nogueira et al. 2007). To our knowledge, our capture of this species is the first published record of it in a manmade roost. The three species ( $T$. cirrhosus, L. aurita and D. rotundus) have already been observed sharing the same roost in a cave (Cramer et al. 2001).

\section{General Aspects}

We only found foliage roosts in the urban area. This may be because urban area trees are easier to search than those in forests. The same reasoning may apply for hollows in trees in the rural area, where the clearing of land into plantations and pastures makes such roosts easier to find. Also, bats are restricted to roost fewer options. The higher availability and reduced ease of discovery probably make this kind of roost more difficult for observers to find in forests, providing a possible explanation for us not finding such roosts in the protected area.

To our knowledge we present the first record of Lonchorhina aurita using man-made roosts. Natural history information on roost use is important basic data not only to refine ecological knowledge, but also to devise more effective conservation planning for bats. Roosts are important resources for bats, especially in regions that have experienced significant human pressure. Roosts are of paramount importance to the persistence of bat communities. Knowledge of bat roost ecology will play a vital role in managing and conserving bats. Different bat species often exhibit unique roost preferences and some may require several roosts for different purposes. The maintenance of a wide diversity of roost types in a landscape is a cornerstone to successful conservation of bat diversity.

\section{ACKNOWLEDGMENTS}

We thank Silvia Ramira Lopes Pinto and Merlin D. Tuttle for providing helpfull comments in the first version of the manuscript. We also thank Instituto Brasileiro do Meio Ambiente e dos Recursos Naturais Renováveis (IBAMA) for the fieldwork licenses, the administration of Mosteiro Zen Morro da Vargem park, Valdir Cetto and family for the permission to work on their property, and all collegues that helped in fieldwork. Poliana Mendes thanks UFES/PETROBRÁS for the PIBIC scholarship.

\section{REFERENCES}

Aguiar, L.M.S. 2007. Subfamília Desmodontinae, p. 39-45, In N. Reis, A. Peracchi, E.A. Pedro \& I.P. Lima (eds.). Morcegos do Brasil. Universidade Federal de Londrina, Londrina, Paraná, Brazil.

Ávila-Flores, R., J.J. Flores-Martínez, \& J. Ortega. 2002. Nyctinomops laticaudatus. Mammalian species 697: 1-6

Ávila-Flores, R. \& R.A. Medellín. 2004. Ecological, taxonomic, and physiological correlates of cave use by Mexican bats. Journal of Mammalogy 85: 675-687

Barros, R.S.M., E.L. Bisaggio \& R.C. Borges. 2006. Morcegos (Mammalia, Chiroptera) em fragmentos florestais urbanos no município de Juiz de Fora, Minas Gerais, Sudeste do Brasil. Biota Neotropica 6: 1-6

Bergallo, H.D., C.E.L. Esbérard, M.A.R. Mello, V. Lins, R. Mangolin, G.G.S. Melo \& M. Baptista. 2003. Bat Species Richness in 
Atlantic Forest: What Is the Minimum Sampling Effort? Biotropica 35: 278-288

Cloutier, D. \& C.H. Tomas. 1992. Carollia perspicillata. Mammalian species $417: 1-9$

Cramer, M.J., M.R. Willig \& C. Jones. 2001. Trachops cirrhosus. Mammalian species 656: 1-6

Esbérard, C.E.L. \& H.G. Bergallo. 2004. Aspectos sobre a biologia de Tonatia bidens (Spix) no estado do Rio de Janeiro, sudeste do Brasil (Mammalia, Chiroptera, Phyllostomidae). Revista Brasileira de Zoologia 21: 253- 259

Esbérard, C.E.L. \& C. Daemon. 1999. Um novo método para marcação de morcegos. Chiroptera Neotropical 5: 116-117

Esbérard, C.E.L., J.A. Motta \& C. Perigo. 2005. Morcegos cavernícolas da Área de Proteção Ambiental (APA) Nascentes do Rio Vermelho, Goiás. Revista Brasileira Zoociências 7: 311-325

Fabian, M.E. \& R. Gregorin. 2007. Família Molossidae, p.149-167. In N. Reis, A. Peracchi, E.A. Pedro \& I.P. Lima (eds.). Morcegos do Brasil. Universidade Federal de Londrina, Londrina, Paraná, Brazil.

Fenton, M.B., M.J. Vonhof, S. Bouchard, S.A. Gill, D.S. Johnston, F.A. Reid, D.K. Riskin, K.L. Standing, J.R. Taylor, \& R. Wagner. 2000. Roosts used by Sturnira lilium (Chiroptera: Phyllostomidae) in Belize. Biotropica 32: 729-733

Gardner, A.L. 2007. Mammals of South America. Marsupials, Xenarthrans, Shrews, and Bats. The University of Chicago, Chicago, USA.

Greenhall, A.M., U. Schimdt \& G. Joermann. 1984. Diphylla ecaudata. Mammalian species 227: 1-3

Gregorin, R. \& V.A. Taddei. 2002. Chave artificial para a identificação de Molossídeos brasileiros. Mastozoología Neotropical 9:13-32

Handley, Jr. C.O. 1976. Mammals of Smithsonian Venezuelan Project. Science Bulletin of Brigham Young University, Biological Series 20: 1-89

Lassieur, S. \& D.E. Wilson. 1989. Lonchorrhina aurita. Mammalian species 347: 1-4

Keeley, B.W. \& M.D. Tuttle. 1999. Bats in American bridges. Bats Magazine 4: 41

Kerth, G., K. Weissmann, \& B. König. 2001. Day roost selection in female Bechstein's bats (Myotis bechsteinii): a field experiment to determine the influence of roost temperature. Oecologia 126: 1-9

Kunz, T.H. 1982. Roosting ecology, p. 1-56, In T.H. Kunz (ed.). Ecology of Bats. Plenum, New York, USA.

Kunz, T.H. \& L.F. Lumsden. 2003. Ecology of cavity and foliage roosting bats, p. 3-69, In T.H. Kunz \& M.B Fenton (eds.). Bat Ecology. University of Chicago, Chicago, Illinois, USA.

Mendes, P., T.B. Vieira, M. Oprea, S.R. Lopes, A.D. Ditchfield \& M. Zortéa. 2010. O estado do conhecimento sobre morcegos (Chiroptera: Mammalia) do Espírito Santo, sudeste do Brasil. Papéis Avulsos de Zoologia 50: 363-373
Menzel, M. A., S. F. Owen, W. M. Ford, J. W. Edwards, P. B. Wood, B. R. Chapman \& K. V. Miller. 2002. Roost tree selection by northern long-eared bat (Myotis septentrionalis) maternity colonies in an industrial forest of the central Appalachian Mountains. Forest Ecology and Managment 55:107-114

Moussy, C. 2011 Selection of old stone buildings as summer day roost by the brown long-eared bat Plecotus auritus. Acta Chiropterologica 13: 101-111

Neuweiler, G. 2000. The Biology of Bats. Oxford University, Oxford, Oxfordshire, England.

Nogueira, M.R. \& A. Pol. 1998. Observações sobre os hábitos de Rhynchonycteris naso (Wied-Newied, 1820) e Noctilio albiventris (Desmarest, 1818) (Mammalia, Chiroptera). Revista Brasileira de Biologia 58: 473-480

Nogueira, M.R., A.L. Peracchi, \& R. Moratelli. 2007. Subfamília Phyllostominae, p. 61-99, In N. Reis, A. Peracchi, E.A. Pedro \& I.P. Lima (eds.). Morcegos do Brasil. Universidade Federal de Londrina, Londrina, Paraná, Brazil.

Oprea, M. 2007. Urban bats of Brazil: How bats survive when cities invade the forests. BATS Magazine Fall 2007: 9 - 11

Oprea, M., T.B.Vieira, V.T. Pimenta, P. Mendes, D. Brito, A.D. Ditchfield, L.V Knegt \& C.E.L. Esbérard. 2006. Bat predation by Phyllostomus hastatus. Chiroptera Neotropical 12: 255-258

Ortêncio-Filho, H.O., I.P. Lima \& F.N.O. Fogaça. 2007. Subfamília Carollinae, p. 99-106, In N. Reis, A. Peracchi, E.A. Pedro \& I.P. Lima (eds.). Morcegos do Brasil. Universidade Federal de Londrina, Londrina, Paraná, Brazil.

Peracchi, A.L. \& M.R. Nogueira. 2007. Família Emballunoridae, p. 27-34, In N. Reis, A. Peracchi, E.A. Pedro \& I.P. Lima (eds.). Morcegos do Brasil. Universidade Federal de Londrina, Londrina, Paraná, Brazil.

Plumpton, D.L. \& J.K. Jr. Jones 1992. Rhynchonycteris naso. Mammalian Species 413: 1-5

Portfors, C.V., M.B. Fenton, L.M.S. Aguiar, J.E. Baugarten, M.J. Vonhof, S. Bouchard, D.M. Faria, W.A. Pedro, N.I.L. Rauntenbach \& M. Zortéa. 2000. Bats from Fazenda Intervales, Southeastern Brazil-species account and comparison between different sampling methods. Revista Brasileira de Zoologia 17: 533-538

Rodriguez-Herrera, B., R.A. Medéllin \& M. Gamba-Rios. 2008. Roosting requirements of white tent-making bat Ectophylla alba (Chiroptera: Phyllostomidae). Acta Chiropterologica 10: 89-95

Santos, M., L.F. Aguirre, L.B. Vasquez \& J. Ortega. 2003. Phyllostomus hastatus. Mammalian species 722: 1-6

Silva, G. 1979. Los murciélagos de Cuba. Academia, La Habana, Cuba.

Taddei, V.A., L.C. Vizotto \& S.M. Martins. 1976. Notas taxonômicas e biológicas sobre Molossops brachymeles cerastes (Thomas, 1901) (Chiroptera-Molossidae). Naturalia 2: 61-69 
Trajano, E. 1995. Protecting caves for the bats or bats for the caves? Chiroptera Neotropical 1: 19-22.

Vizotto, L.D. \& V.A. Taddei. 1973. Chave para determinação de quirópteros brasileiros. da UNESP, São José do Rio Preto, Brazil.

Yee, D.A. 2000. Peropteryx macrotis. Mammalian Species 643:1-4.

Zortéa, M. 1995. Observations of tent-using in the Carollinae bat Rhinophylla pumilio in southeastern Brazil. Chiroptera Neotropical 1:2-4.
Zortéa, M. 2007. Subfamília Stenodermatinae, p. 107-129, In N. Reis, A. Peracchi, E.A. Pedro \& I.P. Lima (eds.). Morcegos do Brasil. Universidade Federal de Londrina, Londrina, Paraná, Brazil.

Zortéa, M. \& B.F.A. Brito. 2000. Tents use by Vampyressa pusilla (Chiroptera: Phyllostomidae) in southeastern Brazil. Journal of Tropical Ecology 16:475-480. 
